\title{
TECHNICAL EDUCATION IN BASIC SCHOOLS - HISTORY AND PRESENT
}

Čestmír SERAFÍN *, Univerzita Palackého v Olomouci, Česká republika Martin HAVELKA, Univerzita Palackého v Olomouci, Česká republika Jiř́́ KROPÁČ, Univerzita Palackého v Olomouci, Česká republika

Přijato: 10. 1. 2017 / Akceptováno: 14. 7. 2017

Typ článku: Teoretická studie

DOI: $10.5507 /$ jtie.2017.014

Abstract: This paper deals with the context of changing the concept of technical education at basic schools. There will be analysed broader context of process in preparing students at basic schools in the field of technical oriented subjects in $20^{\text {th }}$ and $21^{\text {st }}$ century within the area of the current Czech Republic. In the paper, there is presented a research describing the current situation in the area technical education in schools at Olomouc region.

Key words: Technical education; craft; basic school; pedagogy; technology; teaching; education; training

\section{TECHNICKÁ VÝCHOVA NA ZÁKLADNÍCH ŠKOLÁCH - MINULOST A SOUČASNOST}

Abstrakt: Příspěvek se zaměruje na kontext podmiňujicí změny pojetí technické výchovy na základnich školách. Jsou zde analyzovány širši souvislostí vývoje prípravy žáki̊ na základních školách v oblasti obecně technicky orientovaných předmětů ve 20. a 21. století na území nynějši České republiky. V př́spěvku je uvedeno výzkumné šetření, které popisuje současný stav voblasti technické výchovy ve školách na Olomoucku.

Klíčová slova: Technická výchova; pracovní výchova; základní škola; pedagogika; technika; učitelství; výchova; vzdělávání

*Autor pro korespondenci: cestmir.serafin@upol.cz 


\section{1 Úvod}

Technika a technologie jsou neodmyslitelnou součástí běžného života dnešního člověka. Jedním z úkolů vzdělávacího systému je zpřístupnit co nejširší populaci přinejmenším elementární vhled do této sféry a do života s technikou a technologiemi, zajistit technickou gramotnost. Právě toto je základem technické výchovy prováděné na základních školách, tedy na úrovni ISCED1 a ISCED2.

Všeobecné vzdělávání nové generace bylo a zřejmě i v budoucnu bude spojeno mnoha otázkami a obtížnými souvislostmi, jeho koncepce nebude jednoduchou záležitostí. Pohledem do minulosti vidíme a také dnes je zdůrazňováno, že rozvoj každé společnosti je závislý na dobré vzdělanosti, podmiňující mj. uplatnění vědy, techniky a technologií. Technika je dnes součástí všech oblastí lidského konání - ekonomického, společenského, kulturního i politického. Je nutné, aby uvedené bylo respektováno i při koncipování školského systému a při vytváření vzdělávacího kurikula.

Základní vzdělávání má za cíl poskytnout komplexní všeobecné vzdělání, které je rozhodující pro další život jedince a je nezastupitelné. V tomto všeobecném vzdělávání má mít své pevné místo i technické vzdělávání, které ve spojení s další výukou dává žákům základní technické znalosti a dovedností, rozvíjí technické myšlení, kreativitu a tím napomáhá rozvoji klíčových kompetencí žáků pro další život ve společnosti. Všeobecně pojaté technické vzdělávání působí také jako integrující činitel pro většinu př́rodovědných předmětů a představuje tudíž povinnou součást tohoto vzdělávání.

Za hlavní cíle technického vzdělávání lze pokládat:

1. Rozvíjení myšlenkového potenciálu žáků (rozvíjení myšlenkové aktivity, rozvíjení komunikativní dovednosti, týmová spolupráce, formuje se osobnost žáka, atd.).

2. Objasňování postavení techniky v kontextu člověka (vývoj techniky, vztah mezi technikou a společností, technická gramotnost, atd.).

3. Rozvíjení dovednosti řešení problémů (tvořivé technické myšlení, kooperativní učení, badatelské učení, využivání informačních technologií, projektová výuka, atd.).

4. Objasňování vlivu techniky na společnost a prŕrodu (vliv techniky a technologií na životní prostředí, vztah k př́rodním zdrojům, ekologie, vliv techniky na člověka, atd.).

5. Rozvíjení poznatků o technice (použivání nástrojů, strojů a zařízení, poznávání materiálů a technologií, využití informačních technologií v technických procesech, konstruování, měření, modelování, atd.).

6. Rozvíjení schopnosti hodnocení a sebehodnocení (vztah k technice, technická zájmová činnost, pozitivní vztah k práci, schopnost seberegulace a sebehodnocení, atd.).

7. Podporovat integraci s dalšími předměty (projektové vyučování, badatelská výuky, atd.).

Tyto cíle lze pokládat za reflexi požadavků společnosti na všeobecné pojetí technického vzdělávání.

Záměrem stati je z uvedených pozic nejprve prezentovat souvislosti změn pojetí, jimiž procházelo technické vzdělávání na základních školách podle měnících se společenských požadavků na něj. V další části je předložena analýza obsahového zaměření, popř. zastoupení jednotlivých tematických okruhů vzdělávací oblasti Člověk a svět práce $\mathrm{v}$ jednotlivých ročnících 2 . stupně základních školy v Olomouci a jejím okolí. 


\section{Použité metody}

V části 3 a 4 byla využita především činnost $\mathrm{s}$ informačními prameny, nesoucí charakter teoretických metod pedagogického výzkumu. Prováděna byla klasifikační a vztahová analýza př́islušných částí obsahu pedagogické teorie, ale především vzdělávací dokumentace. Byly srovnávány a trríděny podstatné rysy pojetí výuky v kontextu požadavků na ni, sledovány tedy byly vztahy mezi oprávněnými požadavky na technické vzdělání populace a realitou technického vzdělávání na vzorku základních škol.

Část 5 obsahuje výzkumné šetření, jež proběhlo analýzou Školních vzdělávacích programů základních škol v Olomouci a okolí; analyzováno bylo zastoupení jednotlivých tematických okruhů vzdělávací oblasti Člověk a svět práce v jednotlivých ročnících 2. stupně základní školy; ve vybraných př́padech proběhly osobní konzultace s učiteli na vybraných školách.

\section{Technická výchova před rokem 1989}

Skončením existence Rakousko-Uherska a vznikem Československé republiky v roce 1918 bylo potřeba zrevidovat celý vzdělávací systém a postavit ho na moderních základech. To bylo předurčováno myšlením společnosti té doby, ovlivněné osobnostmi jako byl T. G. Masaryk a konkrétněji významnými pedagogy či učiteli - J. Úlehla, následně O. Kádner či O. Chlup. Jejich kritický přístup k pedagogice 18. a 19. století předurčoval vývoj vzdělávání žáků základního vzdělávání počátku 20. století.

Obsah i pojetí výuky o technice (či spíše k technice) na základním stupni vzdělávání té doby zahrnovalo především ruční zpracování různých materiálů, od čehož se odvíjely i názvy vyučovacích předmětů, se kterými se bylo možno setkat - jako Ruční práce chlapecké (J. Němec, 1932) nebo Ruční práce dívčí (E. Langrová, 1936). V obsahu vyučovacích předmětů na tomto stupni vzdělávání se technické objekty v té době př́liš nevyskytovaly, dáno požadavkem na řemeslnou zručnost, ale např́iklad i tím, že tehdejší běžné domácnosti nebyly technickými zařízeními ve větší míře vybaveny (J. E. Koula, 1931).

Po druhé světové válce je vzdělávání v bývalém Československu výrazně ovlivněno sovětskou pedagogikou. V té době byl uplatňován v technické/pracovní činnosti žáků na základním stupni vzdělávání prakticismus - na jedné straně polytechnická výchova a na druhé straně převládající nácvik pracovních operací (J. Dostál a M. Kožuchová, 2016). Hlavním posláním polytechnické výchovy (J. Honzíková, 2016; J. Dostál a V. Prachagool, 2016) se stalo spojení teoretické podoby výuky s praktickou výrobní praxí (tzv. polytechnický princip). Jeden z nejvýraznějších problémů pracovní výchovy té doby se stal problém tzv. manualismu a intelektualismu obsahu této výchovy, dále šlo o problém intensity a extensity použití práce jako prostředku a metody výchovy. Oba tyto okruhy problémů se ve svých důsledcích dotýkaly oblasti cílů, metod i organizace, konečně i funkce učitele a vybavení školy pro realizaci pracovní výchovy.

Mezi předměty realizované na úrovni základního vzdělávání byly tedy po roce 1949 zařazeny předměty pracovně-technického charakteru na podporu polytechnické výchovy, ale už v roce 1953 byly povinné pracovní činnosti zrušeny a do výuky pronikl tzv. polytechnický intelektualismus (J. Dostál, V. Prachagool, 2016, s. 10). Od roku 1960 však bylo od tohoto modelu ustoupeno a byl do učebních osnov začleněn předmět ,pracovni 
vyučováni" ${ }^{\text {“1 }}$, který měl tři samostatné složky (technické práce, pěstitelské práce, specifická připrava divek) a společně s prŕrodovědnými předměty zajistit polytechnické vzdělávání žáků. Tato koncepce byla chápána, jak již zde bylo řečeno, jako přiblížení výrobního procesu žákủm prostřednictvím výrobních aktivit zakomponovaných do pracovního vyučování. Výuka predmětu ,pracovní vyučováni “ v 5. až 8. ročníku základní školy tak byla realizována v prakticky neměnné podobě až do konce 80.tých let minulého století a $\mathrm{z}$ odborného hlediska byla poměrně dobře propracovaná. Technická výchova $\mathrm{v}$ tomto období poskytovala žákủm nezbytné základy technického myšlení a osvojení si technických dovedností, ale také jim napomáhala s výběrem učebního nebo studijního oboru střední školy. Výhodou bylo i to, že předmět „pracovni vyučováni" (technické práce) podporoval a kooperoval s tehdejší zájmovou činností v různých modelářských a jiných kroužcích a více či méně korespondoval s řemeslně amatérskými potřebami tehdejší doby². Z. Rádl (1988) pro žáky napsal: „V technických pracich si budete osvojovat základni znalosti techniky a technického myšleni. Budete rozvíjet svoji technickou prédstavivost. Poznáte rưzné materiály a jejich vlastnosti. Naučite se pracovat s měridly, nástroji, náradím a později, ve vyššich ročnicich, is některými obrábécími stroji. Poučite se o tom, jak plánovat a organizovat práci, jak stanovit pracovni postup. Pod vedením učitele budete rešit zajímavé technické problémy“. To je dobrá formulace, problém tehdy již byl jinde, $v$ malé pozornosti světu techniky, který již začal tehdy žáky hojně obklopovat, ale ve výuce technického předmětu byl málo reflektován. Potřeba rozvíjení manuálních a Z. Rádlem uvedených souvisejících dovedností byla tehdy považována za větší prioritu než ještě před nedávnem (viz následující kapitola č. 4).

\section{Technická výchova po roce 1989}

Společenské změny v roce 1989 vedly k změně v pojetí vzdělávání spojeném s odstraněním ideologie z osnov škol a náplně předmětů (J. Kalous, J. 2009). Počátkem 90 . let 20. století se stala běžným standardem možnost vypouštět z osnov až $30 \%$ učiva, pro něž nebyly ve škole odpovídající podmínky, rovněž učitelé začali zkoušet nové př́istupy. Tak se začalo, poněkud živelně, pozitivně měnit vzdělávání v České republice. Tyto změny se však dosti často negativně dotýkaly technického/pracovního vzdělávání, ustupovalo se od něj a tehdejší výuka, silně založená na manuálních činnostech a polytechnickém principu chápaném zejména jako sepětí s výrobou, byla na mnoha školách potlačována. Byla považována jako v nových poměrech nepotřebná a př́islušná předchozímu společenskému zřízení. Nebudeme zde dokazovat, že šlo o omyl, v demokratických státech výuka technických předmětů na školách stupně ISCED 1

\footnotetext{
${ }^{1}$ Tato etapu postupného zavádění učebních osnov pracovního vyučování znamenala údobí, ve kterém se na bývalých osmiletých a jedenáctiletých středních školách vyučovalo ve školních dílnách $\mathrm{v}$ rámci učebního předmětu praktická cvičení ve školních dílnách a na školních pozemcích a na bývalých výzkumných dvanáctiletých středních školách v rámci učebního předmětu základy výroby.

${ }^{2}$ Názorně dokládá citát: „Před rokem 1989 si většina Čechů zakládala na tom, že všechny odborné profese zvládne sama. Zkrátka co Čech, to chalupář, co chalupář, to řemeslník. Byla to ovšem svým způsobem $\mathrm{z}$ nouze ctnost. Sehnat řemeslníka býval problém“ (http://www.radio.cz/cz/rubrika/ekonomika/vrati-se-doba-kdy-kazdy-druhy-cech-byl-amaterskyremeslnik).
} 
a ISCED 2 své místo má, vhodnější by bylo výuku postupně reformovat, což v části škol skutečně proběhlo.

Všeobecně lze říci, že vznikaly alternativní vzdělávací obsahy, kdy teoretikové začali hledat motivaci pro reformní kroky dalších let v západoevropském školství. V průběhu roku 1991 tak vzniklo celkem šest projektů transformace českého školství (D. Greger, 2011). Za jeden z nejvýznamnějších projektů té doby lze považovat práci J. Kotáska a kolektivu (J. Kotásek, 1991) s názvem Budoucnost vzdělání a školství v obnovené demokratické společnosti a ve sjednocujici se Evropě, který je souhrnem volných statí různých autorů $\mathrm{s}$ názory na jednotlivé oblasti školství nebo projekt NEMESu (M. Havlínová a kol., 1991) s názvem Svoboda ve vzdělání a česká škola, obsahující filozofická východiska, představu o budoucí škole, která byla následně doplněna principy realizace.

V roce 1994 MŠMT ČR vydalo dokument Program rozvoje vzdělávací soustavy České republiky - Kvalita a odpovědnost, kde byly poprvé formulovány zásady nové kurikulární politiky jako východisko př́pravy nového školského zákona. Vzdělávací program Základní škola v roce byl schválen v roce 1996 s takzvanými osnovami a učebním plánem platným od 1. 9. 1996. Dle učebního plánu tohoto vzdělávacího programu byla minimální časová dotace pro předmět ,praktické činnosti“ v 6. až 9 . ročníku pouhé 4 vyučovací hodiny. Navíc program umožnil řediteli rozhodnout o výběru tematických celků $\mathrm{v}$ jednotlivých ročnících dle podmínek školy. Tento princip vedl k tomu, že se praktické činnosti začaly rušit (přispěl k tomu i fakt, že začalo scházet odpovídající materiální vybavení školních dílen, ruční nářadí z 80 . let minulého století již nevyhovovalo a chyběly finance na nákup nového, scházel materiál i aprobovaní učitelé).

$\mathrm{Na}$ počátku nového tisíciletí přišla euforie v podobě rozvoje informační gramotnosti žáků i učitelů. Ve školách byl zvolen tematický celek ,práce s počitačem“ jako hlavní nahrazující náplň pracovních činností. Ředitelé pod dojmem rozvoje informační společnosti výuku „Práce s technickými materiály“ nebo „Elektrotechniku kolem nás“ z procesu vzdělávání úplně omezovali. Vznikla tak škoda, protože dnes se situace vrací a zřetelně se hovoří o tom, že bychom měli u dětí rozvíjet jak manuální zručnost a kreativitu při práci s materiály a následně technické myšlení. Decizní sférou jsou konečně tyto snahy zřetelně podporovány (mj. i prostředky fondů Evropské unie).

Vrat'me se ale na počátek tisíciletí. V roce 2004 byla schválena nová politika vzdělávání žáků od 3 do 19 let v podobě tzv. rámcových vzdělávacích programů. Od roku 2004 jsou tak v České republice realizovány dvě vzdělávací úrovně, a to státní a školská. Státní úroveň představuje Národní program pro rozvoj vzdělávání (tzv. Bílá kniha) a rámcové vzdělávací programy. Národní program vzdělávání vymezuje počáteční vzdělávání jako celek a rámcové programy pak vymezují závazné „rámce“ pro jednotlivé etapy vzdělávání (předškolní, základní a střední vzdělávání). Školní úroveň pak představují školní vzdělávací programy, podle kterých se uskutečňuje výuka na jednotlivých školách.

V rámci základního vzdělávání je technická/pracovní výchova realizována ve vzdělávací oblasti Člověk a svět práce (RVP ZV, 2016). Tato vzdělávací oblast se zaměřuje na pracovní činnosti a technologie směrem $\mathrm{k}$ uživatelským dovednostem $\mathrm{v}$ různých oborech lidské činnosti, včetně vytváření životní a profesní orientace žáků. Koncepce má vycházet z konkrétních životních situací, s nimiž žáci mohou přicházet do kontaktu. Časová dotace je však na prvním stupni základní školy minimálně 5 hodin a na druhém stupni pouhé 3 hodiny týdně, prričemž v rámci této oblasti mají být realizovány 
tematické okruhy Práce s drobným materiálem, Konstrukční činnosti, Pěstitelské práce, Př́prava pokrmů na 1. stupni (zde jsou pro školu povinné), zatímco na 2 stupni jsou to tematické okruhy Práce s technickými materiály, Design a konstruování, Pěstitelské práce a chovatelství, Provoz a údržba domácnosti, Př́prava pokrmů, Práce s laboratorní technikou, Využití digitálních technologií, Svět práce. Na 2. stupni je tematický okruh Svět práce povinný, z dalších uvedených tematických okruhů školy vybírají podle svých podmínek a pedagogických záměrů minimálně jeden další; vybrané realizují v plném rozsahu.

\section{Aktuální stav technické výchovy}

V roce 2013 proběhlo výzkumné šetření na základních školách Olomouckého regionu (Serafín, Č. a kol., 2016). Tento region byl vybrán ze dvou důvodů - jednak spádovosti př́pravy učitelů na oblast technické výchovy, kdy se zde koncentrovala základní kohorta učitelů připravovaná pro tuto oblast na pedagogických fakultách v Ostravě, Brně, a především v Olomouci a dále vlastní skladbou škol v regionu, jenž vhodně umožňoval náhodný výběr dvaceti základních škol v Olomouci a okolí $(40 \%$ je z Olomouce a zbylých $60 \%$ z velkých měst v okolí $40 \mathrm{~km}$ ).

Předmětem analytického šetření školních vzdělávacích programů vybraných škol bylo mj. rozebrat zastoupení jednotlivých tematických okruhů vzdělávací oblasti Člověk a svět práce $\mathrm{v}$ př́slušných ročnících 2 . stupně základní školy. Tedy zda se základní školy vůbec výukou $\mathrm{v}$ omezených rámcích, daných rámcovým vzdělávacím programem a jeho promítnutím do školních vzdělávacích programů jednotlivých škol, zabývají a pokud ano, pak v jaké šírii, nebot' jak již zde bylo řečeno, pouze okruh Svět práce je povinný.

Šetřením bylo zjištěno, že vzdělávací oblast Člověk a svět práce je na posuzovaných školách vyučována svým rozsahem nad rámcovým vzdělávacím programem stanovený hodinový rámec, přičemž se školy $\mathrm{v}$ rámci svých školních vzdělávacích programů snaží postihnout maximum $z$ možných tematických okruhů. $Z$ grafů níže uvedených je však patrné, že zastoupení těchto tematických okruhů v průměru výzkumného vzorku není rovnoměrné, čemuž je věnována následující analýza.

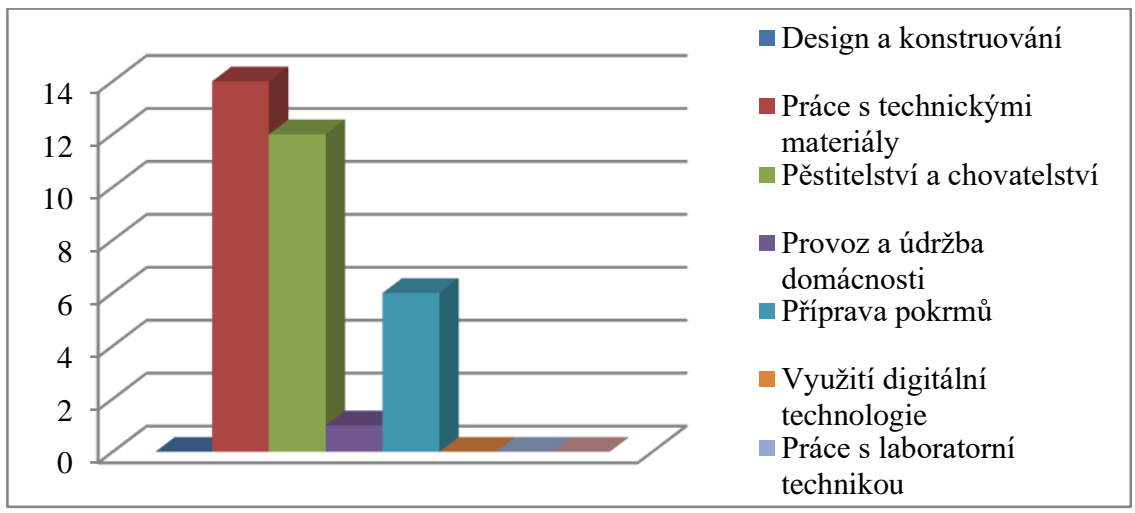

Obr. 1 Četnost zastoupeni jednotlivých tematických okruhů ve výuce vzdèlávaci oblasti Člověk a svět práce v 6. ročnicich na posuzovaných školách 
$\mathrm{Z}$ výše uvedeného (viz obr. č. 1) je patrné, že $\mathrm{v}$ 6. ročníku je výuka věnována práci $\mathrm{s}$ technickými materiály, pěstitelským pracím a chovatelství, přípravě pokrmů, provozu a údržbě domácnosti a designu a konstruování.

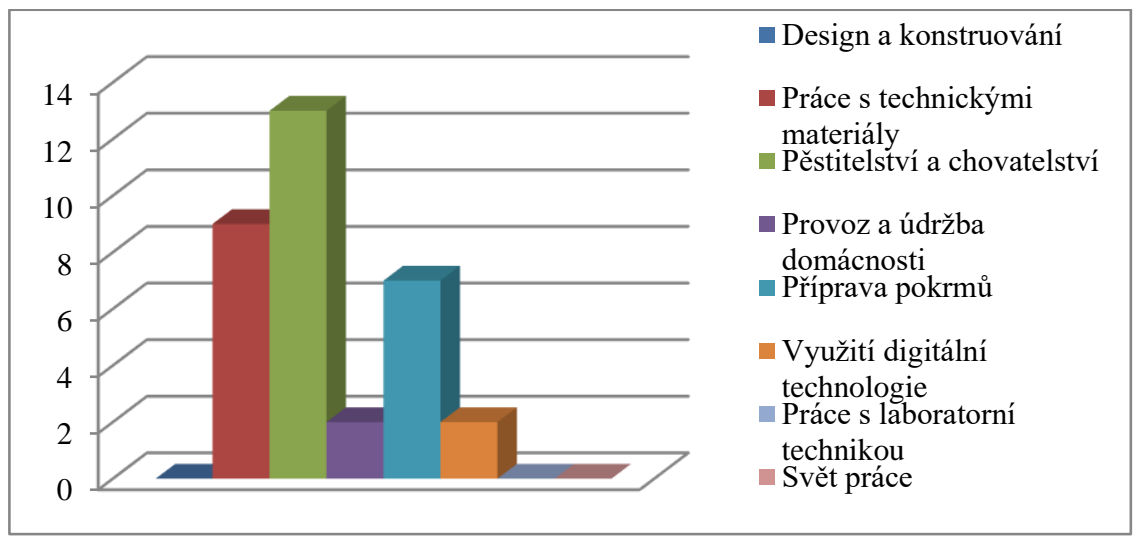

Obr. č. 2: Četnost zastoupení jednotlivých tematických okruhů ve výuce vzdělávací oblasti Člověk a svět práce v 7. ročnícich na posuzovaných školách

Z výše uvedeného (viz obr. č. 2) je patrné, že v 7. ročníku je u vybraných škol výuka zaměřena na pěstitelské práce, práce s technickými materiály, provoz a údržbu domácnosti a využití digitální technologie. Design a konstruování se v 7. ročníku na vybraných školách ve výuce nevyskytuje.

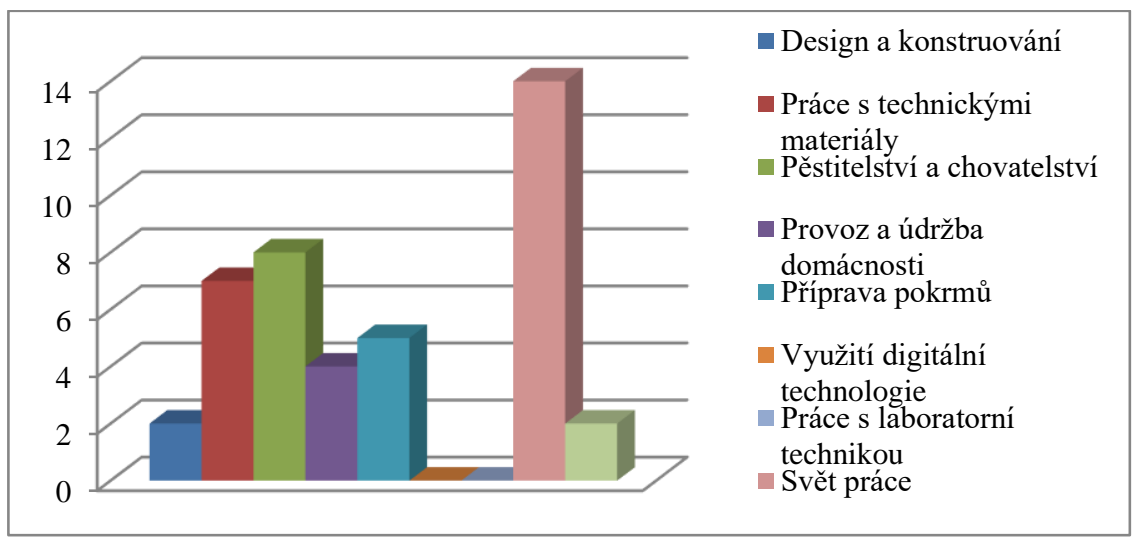

Obr. č. 3: Četnost zastoupení jednotlivých tematických okruhů ve výuce vzdělávací oblasti Člověk a svět práce v 8. ročnicích na posuzovaných školách 
Z výše uvedeného (viz obr. č. 3) je patrné, že v 8. ročníku je u vybraných škol výuka zaměřena na design a konstruování, práci s technickými materiály, pěstitelské práce a chovatelství, provoz a údržbu domácnosti, př́pravu pokrmů, svět práce a design a šití oděvů. Design a konstruování se vyučuje na dvou základních školách z dvaceti vybraných.

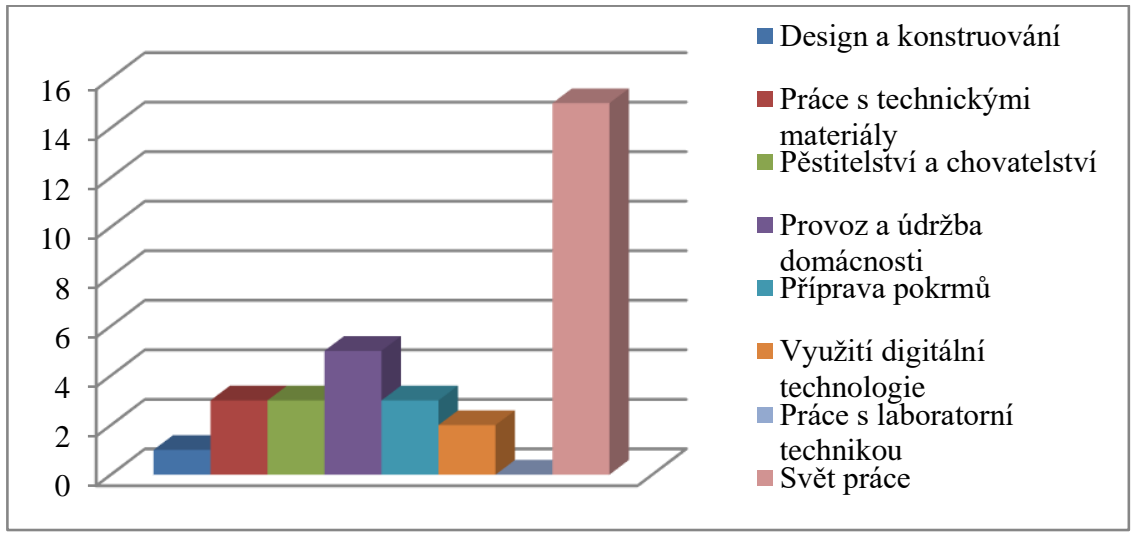

Obr. č. 4: Četnost zastoupení jednotlivých tematických okruhů ve výuce vzdèlávací oblasti Člověk a svět práce v 9. ročnicich na posuzovaných školách

$Z$ výše uvedeného (viz obr. č. 4) je patrné, že výuka v 9. ročníku je převážně vedena k okruhu Svět práce. Jiné tematické okruhy se ve výuce objevují zř́́dka. Výuka tematického okruhu Design a konstruování je vedena pouze na jedné škole z dvaceti vybraných základních škol.

Z výše uvedeného přehledu je patrné, že se výuka ve vzdělávací oblasti Člověk a svět práce od Práce s technickými materiály po Provoz a údržbu domácnosti a pochopitelně Svět práce, kde se koncentruje zejména v posledních ročnících školy otázka volby povolání a další profesní směřování žáka.

Uváděné šetření se dotýká jen velmi malé části problému, který byl v rámci výzkumu zkoumán, přesto však dává určitý obraz (i když na velmi malém vzorku) o stavu naplňování standardů daných Rámcovým vzdělávacím programem ve školní praxí. Cílem pochopitelně není zevšeobecňovat (to $\mathrm{v}$ daném vzorku opravdu nelze), ale dát tyto skutečnosti k úvahám a odborné diskuzi, která by mohla vyústit v širší výzkum.

\section{Závěr}

Technické vzdělávání na základních školách prochází změnou pojetí danou měnícími se společenskými požadavky na něj. Měnit by se mělo směrem k rozvíjení tvořivých dovedností a výchově dobrého uživatele techniky, a to již v relativně nízkém věku (existuje Sdružení technické školky a projekt Technické školky). Odpovídá to potřebám změn významu techniky a situací spojených $\mathrm{s}$ užitím techniky v předpokládaném budoucím životě žáků. 
Do technického vzdělávání na základních školách by měla být zařazována témata významná pro budoucí činnost žáků s technikou, ale pro žáky přitažlivá a disponující i předpoklady $\mathrm{k}$ rozvíjení osobnosti. To lze považovat za významné při vytváření základních koncepcí všeobecného technického vzdělávání jako vzdělávání určeného nejširší skupině adresátů se záměrem připravit je pro život i praxi.

Pohled do minulosti ukazuje, že technické vzdělávání na nižších stupních škol je oprávněné, nepatří však „k inventáŕi“ této výuky. V různých obdobích může být potlačováno, třeba také pro nevhodné jeho pojetí, což je doprovázeno i značnými škodami (podle nás také materiálními, jak jsme mohli vidět). Je proto evidentní, že pokud je toto náročné vzdělávání žádoucí, mělo by mít adekvátní podporu decizní sféry. Často jsme se již setkali s tím, že nemožnost zajistit materiální i další podmínky nezbytné pro výuku aktuálních témat zabránila inovaci.

\section{Literatura}

(1994) Kvalita a odpovédnost, Program rozvoje vzdělávací soustavy České republiky, Praha: MŠMT.

Dostál, J. \& Kožuchová, M. (2016). Badatelský př́stup v technickém vzdělávání: Teorie a výzkum. Olomouc: UP.

Dostál, J. \& Prachagool, V. (2016). Technické vzdělávání na křižovatce - historie, současnost a perspektivy. Journal of Technology and Information Education, 8, č. 2.

Greger, D. (2011). Dvacet let českého školství optikou teorií změny vzdělávání v postsocialistických zemich. Orbis Scholae.

Havlínová, M., Goulliová, K., Hudcová, H. \& Kovařovic J. (1991). Svoboda ve vzdèlání a česká škola: Návrh projektu změny vzdělávacího systému v České republice. Praha: NEMES, Nezávislá mezioborová skupina.

Honzíková, J. (2016) Determinanty polytechnické výchovy v předškolním zařízení Journal of Technology and Information Education. 2016. Volume 8, Issue 2.

Kalous, J. (2009). Transformace české společnosti, školství a vzdělávání po r. 1989. In: Pedagogická encyklopedie, Praha: Portál.

Kotásek, J. a kol.(1991). Budoucnost vzdělání a školstvi v obnovené demokratické společnosti a ve sjednocujici se Evropě. Soubor expertnich studii. Praha: PedF UK.

Koula, J. E. aj. (1931). Obytný dům dneška. Praha: Družstevní práce.

Langrová, E. (1936). Dívčí ruční práce v nové dívči škole. Brno: Zemský spolek učitelek domácích nauk.

Němec, J. (1932). Ruční práce chlapecké na vyšším stupni školy národní: pro potřebu 6., 7. a 8. škol. roku obecných a měštanských škol. Praha: Unie.

Rádl, Z. (1988). Pracovní vyučování: technické práce v 5. ročníku základni školy. 5., přeprac. vyd. Praha: SPN.

RVP ZV (2015) Rámcový vzdèlávací program pro základni vzdělávání [online]. Praha: MŠMT [cit. 2017-06-20]. Dostupné z: http://www.msmt.cz/vzdelavani/zakladnivzdelavani/ucebni-dokumenty

Serafín, Č. a kol. (2016) Proměna kurikula technické výchovy v České a Slovenské republice po roce 1989. Olomouc: VUP. 